\title{
EFEKTIVITAS KEBIJAKAN PENATAAN MINIMARKET DI KABUPATEN BANDUNG PROVINSI JAWA BARAT (Kasus di Kecamatan Cileunyi dan Rancaekek Kabupaten Bandung)
}

Oleh

\author{
Eem Nurnawati \\ Institut Pemerintahan Dalam Negeri \\ eemnurnawati2@gmail.com
}

\begin{abstract}
$M_{e}$ odern market such as minimarket that develops quickly has been recognized as society economical drive. But on the other side, minimarket has been claimed to cause traditional small sellers out of business. To solve this matter, Bandung Regency Government has enacted minimarket order policy in Regional Law No, 20 Year 2009 concerning Market Build, Order, and Control.

This study purpose is to analyze minimarket order policy efficacy in Cileunyi subdistrict and Rancaekek subdistrict. Analysis was run using qualitative descriptive method. Data was collected through observation and documentation techniques, also desk research. Obtained data was analyzed qualitatively using interactive model.

Analysis result showed that minimarket order policy in Cileunyi subdistrict and Rancaekek subdistrict is not yet effective. Some minimarkets operate illegally, some breaks inter outlet minimum distance arrangement, and open 24 hours, interagency policy implementors coordination does not fully work either. Besides, small business and micro business traders have not yet built any cooperation.
\end{abstract}

Keywords: efficacy; minimarket policy order

\begin{abstract}
AbStrak
$\mathrm{K}_{\mathrm{n}}^{\mathrm{e}}$ eberadaan pasar modern semisal minimarket yang berkembang pesat harus diakui telah menjadi penggerak perekonomian masyarakat. Namun, kehadiran minimarket sering kali dikeluhkan menimbulkan matinya pedagang kecil tradisional. Untuk mengatasi hal itu, Pemerintah Kabupaten Bandung telah menetapkan kebijakan penataan minimarket yang terangkum dalam Perda No. 20 Tahun 2009 tentang Pembangunan, Penataan dan Pengendalian Pasar.

Kajian ini bermaksud mengupas efektivitas kebijakan penataan minimarket di Kecamatan Cileunyi dan Rancaekek. Pengkajian dilakukan dengan menggunakan metode deskriptif kualitatif. Data-data dikumpulkan melalui teknik observasi dan dokumentasi serta desk research. Data yang diperoleh dianalisis secara kualitatif menggunakan model interaktif.

Hasil analisis menunjukkan bahwa kebijakan penataan minimarket di Kecamatan Cileunyi dan Rancaekek belum efektif. Diketahui masih ada minimarket yang tidak memiliki izin, tidak mematuhi ketentuan jarak minimal antargerai, dan buka 24 jam, serta lemahnya koordinasi antarlembaga pelaksana kebijakan. Selain itu, belum terwujud kemitraan antara minimarket dengan pelaku usaha kecil dan mikro.
\end{abstract}

Kata kunci: efektivitas; kebijakan penataan minimarket 


\section{PENDAHULUAN}

$\mathrm{K}$ onstitusi Indonesia menjamin hak setiap warga negara untuk memperoleh pekerjaan dan penghidupan yang layak bagi kemanusiaan. UUD 1945 menyebutkan pada Pasal 27 bahwa "Tiap-tiap warga negara berhak atas pekerjaan dan penghidupan yang layak bagi kemanusiaan." Selanjutnya disebutkan pula pada Pasal 28 huruf i ayat (2) bahwa "Dalam menjalankan hak dan kebebasannya setiap orang wajib tunduk kepada pembatasan yang ditetapkan dengan undangundang dengan maksud semata-mata untuk menjamin pengakuan serta penghormatan atas hak dan kebebasan orang lain dan untuk memenuhi tuntutan yang adil sesuai dengan pertimbangan moral, nilai-nilai agama, keamanan, dan ketertiban umum dalam suatu masyarakat demokratis." secara harfiah, ketentuan tersebut dapat diterjemahkan bahwa setiap anggota masyarakat mempunyai kebebasan melakukan usaha sebagai mata pencaharian untuk memenuhi kebutuhan hidupnya. Namun di sisi lain, kebebasan tersebut haruslah tetap berada dalam koridor aturanaturan hukum serta norma-norma etika yang berlaku. Dalam hal ini negara hadir melalui serangkaian regulasi yang mengatur tata etika melakukan usaha sehingga tidak terjadi persaingan yang tidak sehat di antara para pelakunya. Demikian pula halnya dalam penataan pasar modern, salah satunya dalam bentuk minimarket, yang terus berkembang seiring dengan tingginya kebutuhan masyarakat terhadap barang konsumsi.

Perkembangan minimarket dalam satu dekade terakhir menunjukkan tren yang terus meningkat. Bukan hanya di wilayah perkotaan, minimarket saat ini telah merambah hingga wilayah perdesaan. Kondisi ini mendorong pemerintah daerah, sesuai kewenangannya, untuk turun tangan menata serta mengontrol keberadaan minimarket. Langkah konkret yang dilakukan oleh pemerintah daerah adalah dengan mengeluarkan Peraturan Daerah (Perda) beserta peraturan pelaksanaannya yang berisi antara lain ketentuan zonasi, perizinan, dan jam buka minimarket.

Pemerintah mengemban kewajiban melakukan penataan pasar modern, khususnya dalam hal ini minimarket, agar keberadaannya tidak "membunuh" pasar dan pedagang tradisional. Pasalnya, banyak kalangan yang menganggap bahwa keberlangsungan pasar tradisional terancam oleh kehadiran pasar modern. Bukan hanya pasar tradisional, warung-warung di level pengecer pun dapat saja tersingkir karena kalah bersaing dengan minimarket, seperti Indomaret, Alfamart, Yomart, yang keberadaannya semakin "menjamur".

Bagi masyarakat, berbelanja di minimarket dianggap lebih nyaman. Selain itu, ada beberapa faktor yang mengundang animo masyarakat untuk berkunjung dan berbelanja di minimarket, yaitu letaknya yang mudah dijangkau, tampilan toko berikut tatanan produk dagangan yang menarik, tersedianya halaman untuk parkir kendaraan, pilihan barang yang beragam, tempatnya bersih, transaksi jual-beli lebih mudah karena sifatnya yang swalayan, serta jam buka yang jelas dan panjang, bahkan ada minimarket tertentu yang buka 24 jam.

Guna menyiasati perkembangan minimarket, Pemerintah Kabupaten Bandung telah mengeluarkan kebijakan berupa Perda No. 20 Tahun 2009 tentang Pembangunan, Penataan dan Pengendalian Pasar yang dilanjutkan dengan ditetapkannya Perbup No. 60 Tahun 2014 tentang Perubahan atas Perbup No. 29 Tahun 2010 tentang Petunjuk Pelaksanaan PerdaNo.20Tahun 2009. Produk 
hukum daerah tersebut menjadi perangkat regulasi yang mengatur keberadaan pasar di wilayah Kabupaten Bandung, baik itu berupa pasar tradisional maupun pasar modern. secara garis besar, setidaknya ada dua tujuan dari ditetapkannya kebijakan terkait pasar tersebut, yaitu:

1. Memberikan landasan hukum dalam pelaksanaan upaya perlindungan, penataan, dan pemberdayaan terhadap pasar rakyat, pusat pembelanjaan, dan toko swalayan di Kabupaten Bandung.

2. Memberikan perlindungan dan penataan pasar tradisional agar mampu berkembang, melalui kemitraan antara pasar modern dengan pasar tradisional sebagai tindak lanjut dari perkembangan usaha perdagangan eceran dalam skala kecil dan menengah, serta besar yang demikian pesat.

Secara sederhana, dapat dikatakan bahwa Pemerintah Kabupaten Bandung menganggap perlu adanya kebijakan penataan minimarket, baik dalam hal perizinan, lokasi, dan jam buka. Akan tetapi sejauh ini diketahui bahwa kebijakan tersebut belum terimplementasikan sesuai harapan berdasarkan beberapa fakta sebagai berikut.

1. Masih ada minimarket yang belum memiliki izin. Hasil pendataan ulang yang dilakukan oleh Dinas Perindustrian dan Perdagangan, diketahui terdapat 347 minimarket di Kabupaten Bandung di mana hanya 168 yang telah memiliki izin lengkap (HU Pikiran Rakyat, 6-122013).

2. Satuan Polisi Pamong Praja telah melakukan penyegelan terhadap setidaknya 40 minimarket karena belum mengurus izin usaha (https://news. detik.com, 22-9-2017).

3. Adanya minimarket yang berdiri dan beroperasi di jalan desa, sedangkan menurut Bupati Bandung, Dadang $\mathrm{M}$. Naser, di jalan desa tidak boleh ada mini market dan kalaupun ada harusnya ditutup (https://news.detik.com, 22-92017).

4. Ketentuan bahwa minimarket harus menjalin kemitraan dengan UMKM lokal belum dilaksanakan. Berdasarkan catatan Dinas Perindustrian dan Perdagangan, baru terdapat delapan produk industri kecil menengah yang berhasil menembus minimarket (https://www.ayobandung. com, 19-3-2018).

Sebagaimana yang berlangsung di daerah lain, perkembangan minimarket yang demikian pesat juga terjadi di Kecamatan Cileunyi dan Rancaekek.

Tabel 1. Jumlah Pasar/Toko Modern di Kecamatan Cileunyi dan Rancaekek

\begin{tabular}{|c|c|c|c|c|}
\hline \multirow[b]{2}{*}{ No } & \multirow{2}{*}{$\begin{array}{c}\text { Pasar/ } \\
\text { Toko Modern }\end{array}$} & \multicolumn{2}{|c|}{ Kecamatan } & \multirow[b]{2}{*}{ Jumlah } \\
\hline & & $\begin{array}{c}\text { Cileu- } \\
\text { nyi }\end{array}$ & $\begin{array}{c}\text { Ranca- } \\
\text { ekek }\end{array}$ & \\
\hline 1 & Borma & 1 & - & 1 \\
\hline 2 & Griya & 1 & 1 & 2 \\
\hline 3 & Indomaret & 44 & 24 & 68 \\
\hline 4 & Alfamart & 18 & 17 & 35 \\
\hline 5 & Yomart & 2 & 10 & 12 \\
\hline & Jumlah & 66 & 52 & 118 \\
\hline
\end{tabular}

Sumber: BPS Kabupaten Bandung, 2018

Maraknya minimarket di Kecamatan Cileunyi dan Rancaekek tidak lepas dari beberapa faktor, antara lain, yaitu:

1. Letak geografis yang strategis, di mana kedua kecamatan yang saling bertetangga ini merupakan pintu masuk dan keluar Kota Bandung (ke arah Sumedang, Majalengka, Cirebon di jalur utara dan ke arah Garut, Tasikmalaya, Ciamis, Banjar di jalur selatan). Selain itu, kedua kecamatan menjadi lokasi pintu Tol Purbaleunyi (PuwakartaBandung-Cileunyi).

2. Kedua kecamatan berdekatan dengan kawasan pendidikan Jatinangor Kabupaten Sumedang. 
3. Jumlah area permukiman, berupa kompleks perumahan, yang terus meningkat.

Tiga faktor di atas menjadikan besarnya jumlah penduduk serta tingginya lalu lintas manusia di kedua kecamatan tersebut. Kondisi ini tentunya menyebabkan peningkatan kebutuhan terhadap barang konsumsi sehingga menjadi peluang besar bagi minimarket untuk menjalankan usahanya. Beberapa fenomena yang tertangkap terkait dengan keberadaan minimarket di Kecamatan Cileunyi dan Rancaekek antara lain sebagai berikut.

1. Sampai dengan akhir tahun 2018, tercatat ada 64 minimarket yang beroperasi di Kecamatan Cileunyi, terdiri dari Indomaret (44 unit), Alfamart (18 unit), dan Yomart (2 unit). Sementara itu, di Kecamatan Rancaekek terdapat 51 minimarket, terdiri dari Indomaret (24 unit), Alfamart (17 unit), serta Yomart (10 unit).

2. Data pada Kecamatan Cileunyi Dalam Angka 2017 dan 2018 menunjukkan bahwa ada 31 minimarket di kecamatan ini. Artinya, ada 33 minimarket yang tidak atau belum terdata, atau bahkan belum memiliki izin lengkap.

3. Data pada Kecamatan Rancaekek Dalam Angka 2017 dan 2018 memperlihatkan bahwa di kecamatan ini ada 42 minimarket. Dengan demikian, ada 9 minimarket yang tidak atau belum terdata, atau bahkan belum memiliki izin lengkap.

4. Masih ditemui adanya minimarket yang buka 24 jam, baik di Kecamatan Cileunyi maupun Kecamatan Rancaekek, sedangkan ketentuan yang berlaku menyebutkan jam buka minimarket dibatasi pukul 09.00 - 22.00 WIB kecuali bagi yang memiliki izin khusus dari Bupati Bandung.
Temuan-temuan di atas mendasari timbulnya pertanyaan tentang "Sejauh mana efektivitas kebijakan penataan minimarket di Kabupaten Bandung, khususnya di Kecamatan Cileunyi dan Rancaekek?"

Produk hukum daerah, termasuk Perda No. 20 Tahun 2009 serta Perbup No. 60 Tahun 2014, dapat dikategorikan sebagai kebijakan publik. Hal ini mengacu pada definisi yang menyebutkan bahwa "Policy as decision of government" (kebijakan sebagai keputusankeputusan pemerintah) (Hogwood dan Gunn dalam Wahab, 2011: 16). Sejalan dengan definisi tersebut, kebijakan publik mengandung pengertian sebagai "Whatever government choose to do or not to do" (Bridgman dalam Suharto, 2011: 3). Artinya, kebijakan adalah apa saja yang dipilih oleh pemerintah untuk dilakukan atau tidak dilakukan. Kedua definisi itu menunjukkan bahwa kebijakan dapat diartikan sebagai keputusan atau ketetapan pemerintah untuk melakukan suatu tindakan yang dianggap akan membawa dampak bagi kehidupan warganya.

Sebagai sebuah kebijakan, maka Perda No. 20 Tahun 2009 dan Perbup No. 60 Tahun 2014, yang berlaku pula sebagai instrumen hukum guna menata minimarket, harus diimplementasikan. Sesuai dengan tujuannya, melalui kebijakan tersebut diharapkan bahwa keberadaan minimarket harus sesuai dengan peraturan yang ada, dilengkapi izin usaha, serta tidak mengganggu kelangsungan hidup pedagang tradisional. Manakala tujuan tersebut tidak atau belum terwujud, maka kebijakan penataan minimarket belum sepenuhnya efektif bila dikaitkan dengan hakikat efektivitas.

Menurut Uha (2014: 223) efektivitas merupakan bentukan kata efektif yang berasal dari bahasa Inggris, yaitu effective, artinya berhasil atau sesuatu yang dilakukan berhasil dengan baik. Efektivitas hampir selalu dikaitkan dengan pencapaian target 
atau tujuan berdasarkan pendapatpendapat berikut ini.

- Efektivitas mempunyai

\section{pengertian}

pengukuran

$$
\text { sebagai }
$$

tercapainya sasaran dan

tujuan yang telah ditentukan sebelumnya (Emerson dalam Iskandar, 2005: 329).

- Efektivitas merupakan suatu

\section{ukuran yang memberikan}

gambaran seberapa jauh target dapat dicapai (Sedarmayanti, 2009: 59).

- Efektivitas berhubungan dengan tujuan organisasi, baik secara eksplisit maupun implisit (Silalahi, 2011: 128).

- Efektivitas terkait dengan hubungan antara hasil yang diharapkan dengan hasil yang sesungguhnya dicapai (Mahmudi, 2013: 86).

- Efektivitas adalah konsep yang luas mencakup berbagai faktor di dalam maupun di luar organisasi, yang berhubungan dengan tingkat keberhasilan organisasi dalam usaha untuk mencapai tujuan atau sasaran organisasi (Stoner dalam Darsono dan Siswandoko, 2011: 196).

- Efektivitas adalah seberapa baik tujuan yang dapat dicapai, merupakan prestasi yang dicapai dibandingkan dengan yang mungkin dicapai, dengan tetap mempertahankan mutu (Sumanth dalam Darsono dan Siswandoko, 2011: 196).

- Dalam hal pelaksanaan suatu kegiatan organisasi publik, efektivitas berkenaan dengan dampak suatu keluaran/output bagi pengguna jasa (masyarakat) (Soleh dan Suripto, 2011: 26).

Sehubungan dengan efektivitas suatu kebijakan, perlu diperhatikan mekanisme sebuah kebijakan dalam kerangka manajemen sebagaimana tampak pada Gambar 1.

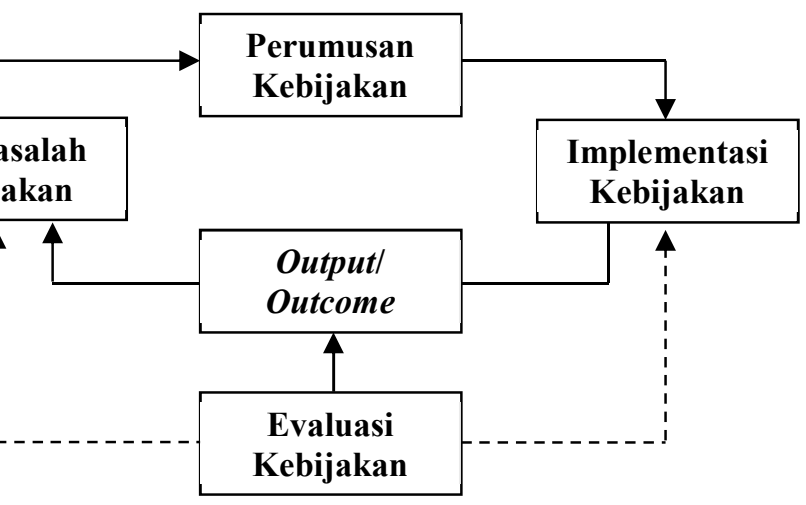

Gambar 1.

Mekanisme Kebijakan (Nugroho, 2003: 73)

Gambar 1 di atas menjelaskan perihal siklus sebuah kebijakan yang meliputi enam hal berikut (Nugroho, 2014: 199-200).

- Terdapat isu/masalah kebijakan. Disebut isu apabila bersifat strategis, mendasar, menyangkut banyak orang, atau bahkan keselamatan bersama. Isu kebijakan terdiri dari problem dan goal. Artinya, kebijakan publik dapat berorientasi kepada permasalahan yang muncul pada kehidupan publik dan dapat pula berorientasi kepada tujuan yang hendak dicapai pada kehidupan publik.

- Isu kebijakan kemudian menggerakkan pemerintah untuk merumuskan kebijakan publik dalam rangka menyelesaikan masalah.

- Setelah dirumuskan, kebijakan publik dilaksanakan oleh pemerintah bersamasama dengan masyarakat.

- Dalam proses perumusan, pelaksanaan, dan pasca pelaksanaan, diperlukan tindakan evaluasi untuk menilai apakah kebijakan tersebut dirumuskan dengan baik dan benar serta diimplementasikan dengan baik dan benar pula.

- Implementasi kebijakan bermuara kepada output yang dapat berupa kebijakan itu sendiri maupun manfaat langsung yang dapat dirasakan oleh pemanfaatan.

- Dalam jangka panjang, kebijakan menghasilkan outcome dalam bentuk 
dampak kebijakan yang diharapkan semakin meningkatkan tujuan yang hendak dicapai dengan kebijakan tersebut.

Berdasarkan enam hal penting dalam siklus kebijakan di atas, dapat dikemukakan empat "tepat" agar sebuah kebijakan dapat efektif, yaitu:

1. Tepat kebijakan, yang dinilai dari sejauh mana kebijakan yang ada telah bermuatan hal-hal yang memang memecahkan masalah yang hendak dipecahkan.

2. Tepat pelaksana. Aktor implementasi kebijakan tidak hanya pemerintah. Ada tiga lembaga yang dapat menjadi pelaksana, yaitu pemerintah, kerja sama antara pemerintah dan masyarakat swasta, atau implementasi kebijakan yang diswastakan.

3. Tepat target, yang berkenaan dengan apakah target yang diintervensi sesuai dengan yang direncanakan serta apakah targetnya dalam kondisi siap untuk diintervensi.

4. Tepat lingkungan, yang meliputi lingkungan kebijakan yakni interaksi di antara lembaga perumus kebijakan dan pelaksana kebijakan dengan lembaga lain yang terkait, serta lingkungan eksternal kebijakan yang terdiri dari public opinion yakni persepsi publik terhadap kebijakan dan implementasi kebijakan.

\section{METODE PENELITIAN}

Pengkajian perihal efektivitas kebijakan penataan minimarket di Kabupaten Bandung, terkhusus di Kecamatan Cileunyi dan Rancaekek, dilakukan dengan menggunakan metode penelitian deskriptif kualitatif. Penelitian deskriptif merupakan penelitian yang bertujuan untuk memberikan atau menjabarkan suatu keadaan atau fenomena yang terjadi saat ini dengan menggunakan prosedur ilmiah untuk menjawab masalah secara aktual (Sugiyono, 2017: 6).

Penelitian kualitatif menghendaki pelaksanaan penelitian berdasarkan pada situasi wajar (natural setting) sehingga kerap disebut sebagai metode naturalistik. Beberapa ciri penelitian kualitatif antara lain adalah bersifat alamiah, bersifat deskriptif, sasaran penelitian berlaku sebagai subjek penelitian (informan), analisis data dilakukan secara induktif (Idrus, 2016: 2324). Analisis induktif berpijak pada faktafakta yang bersifat khusus, kemudian diteliti dan akhirnya menemukan pemecahan persoalan yang bersifat umum. Induktif merupakan cara berpikir untuk menarik suatu simpulan umum dari berbagai kasus yang bersifat individual (Mardalis, 2014: 21).

Data-data sebagai bahan analisis dikumpulkan melalui dua teknik, yaitu observasi dan dokumentasi. Selain itu digunakan pula teknik desk research guna memperoleh data-data yang diperlukan. Data-data tersebut selanjutnya dianalisis secara kualitatif dengan menggunakan model interaktif. Aktivitas analisis dalam model interaktif meliputi langkah data reduction, data displai, dan conclusion drawing/verification (Miles dan Huberman dalam Sugiyono, 2014: 246).

\section{HASIL DAN PEMBAHASAN}

Penilaian tentang efektivitas sebuah kebijakan dapat dilakukan dengan mengacu pada pendapat Nugroho (2014: 199-200) perihal siklus kebijakan yang mencakup enam faktor penting, yaitu isu kebijakan, perumusan kebijakan, implementasi kebijakan, evaluasi kebijakan, hasil (ouput) kebijakan, serta dampak (outcome) kebijakan. Berdasarkan keenam faktor penting tersebut, Penulis mengemukakan empat aspek untuk mendeskripsikan efektivitas kebijakan penataan minimarket di Kecamatan Cileunyi dan Rancaekek, yaitu aspek tepat kebijakan, tepat pelaksana, tepat 
target, dan tepat lingkungan. Keempat aspek tersebut dapat dijelaskan satu per satu sebagai berikut.

\section{Tepat Kebijakan}

Kebijakan penataan minimarket di Kabupaten Bandung merupakan bagian tak terpisahkan dari kebijakan penataan pasar yang tertuang dalam Perda Kabupaten Bandung Nomor Perda No. 20 Tahun 2009 tentang Pembangunan, Penataan dan Pengendalian Pasar. Kebijakan tersebut menjadi wujud nyata upaya Pemerintah Kabupaten Bandung untuk memajukan ekonomi daerah serta upaya menyandingkan antara keberlangsungan pasar tradisional dengan perkembangan pasar modern.

Beberapa ketentuan menyangkut kebijakan penataan minimarket, yang merupakan salah satu bentuk pasar modern, meliputi:

a. Minimarket adalah sarana atau tempat usaha untuk melakukan penjualan barang-barang kebutuhan seharihari secara eceran langsung kepada konsumen dengan cara pelayanan mandiri (swalayan). Minimarket merupakan toko modern dengan luas lantai toko sampai dengan $400 \mathrm{~m}^{2}$.

b. Pendirian minimarket wajib memperhatikan kepadatan penduduk, perkembangan Permukiman baru, aksesibilitas wilayah (arus lalu lintas), dukungan/ketersediaan infrastruktur; dan keberadaan pasar tradisional dan warung/toko di wilayah sekitar yang lebih kecil daripada minimarket. Izin pendirian minimarket diutamakan untuk diberikan kepada pelaku usaha yang domisilinya sesuai dengan lokasi minimarket dimaksud.

c. Penyelenggaraan dan pendirian minimarket wajib memenuhi ketentuan, antara lain sebagai berikut.

1) memperhitungkan kondisi sosial ekonomi masyarakat dan keberadaan pasar tradisional, usaha kecil, dan usaha menengah yang ada di wilayah yang bersangkutan;

2) memperhatikan jarak dengan pasar tradisional maupun minimarket lainnya;

3) menyediakan fasilitas yang menjamin minimarket yang bersih, sehat, higienis, aman, tertib dan ruang publik yang nyaman;

4) menyediakan fasilitas tempat usaha bagi UMKM, pada posisi yang samasama menguntungkan;

5) menyediakan fasilitas parkir kendaraan yang memadai;

6) menyediakan sarana pemadam kebakaran dan jalur keselamatan bagi petugas maupun konsumen;

7) izin usaha minimarket wajib memperhatikan pertimbangan Kepala Desa/Lurah dan BPD/LPM.

d. Minimarket dapat berlokasi pada setiap sistem jaringan jalan, termasuk pada sistem jaringan lingkungan pada kawasan pelayanan lingkungan (perumahan). Jumlah minimarket untuk setiap kawasan perumahan maksimal hanya dua minimarket dalam jarak $2 \mathrm{~km}$.

e. Jam buka minimarket adalah: Senin Jumat (pukul 09.00 WIB - 22.00 WIB), Sabtu dan Minggu (pukul 09.00 - 23.00 WIB), hari besar keagamaan, libur nasional atau hari tertentu lainnya (pukul 09.00 - 24.00 WIB).

f. Setiap pengelola minimarket mempunyai kewajiban menjalin kemitraan dengan usaha UMKM dan koperasi pasar untuk pengelolaan usaha pasar skala besar, menengah dan kecil.

Guna mengimplementasikan kebijakan penataan minimarket, Pemerintah Kabupaten Bandung selanjutnya menetapkan Perbup No. 29 Tahun 2010 tentang Petunjuk Pelaksanaan Perda No. 20 Tahun 2009 yang 
kemudian diubah dengan Perbup No. 60 Tahun 2014. Perbup ini memuat antara lain rincian ketentuan-ketentuan tentang minimarket sebagaimana tersebut di atas. Dilihat dari aspek "tepat kebijakan", dapat dinyatakan bahwa kebijakan penataan minimarket merupakan langkah tepat guna mengantisipasi serta mengatasi persaingan tidak sehat di antara para pelaku usaha perdagangan tingkat eceran (ritel). Hal ini terlihat dari beberapa tujuan ditetapkannya kebijakan penataan minimarket, antara lain, yaitu:

a. Melindungi dan memberdayakan UMKM, koperasi, pedagang kecil, dan pasar tradisional agar mampu berkembang, bersaing, tangguh, maju, mandiri, dan dapat meningkatkan kesejahteraannya;

b. Mengatur dan menata minimarket agar tidak merugikan dan mematikan UMKM, koperasi, pedagang kecil, dan pasar tradisional yang telah ada.

c. Menjamin terselenggaranya kemitraan antara pelaku usaha pasar tradisional, UMKM, dan koperasi dengan pelaku usaha pasar modern berdasarkan prinsip kesamaan dan keadilan dalam menjalankan usaha di bidang perdagangan.

d. Menciptakan kesesuaian dan keserasian lingkungan berdasarkan tata ruang wilayah.

Berdasarkan pengamatan, keempat tujuan di atas belum terwujud sepenuhnya di Kecamatan Cileunyi dan Rancaekek. masih banyak ditemui minimarket dan pelaku usaha mikro dan kecil yang bersifat tradisional cenderung jalan sendiri-sendiri dan belum melakukan kemitraan. Banyak pihak justru menganggap kehadiran minimarket telah menimbulkan turunnya omzet warungwarung kelontong di sekitarnya yang telah ada sebelumnya.

\section{Tepat Pelaksana}

Pelaksana atau implementor kebijakan penataan minimarket di Kabupaten Bandung berdasarkan Perbup No. 60 Tahun 2014 meliputi dua SKPD, yaitu Badan Penanaman Modal dan Pelayanan Terpadu Satu Pintu (DPMPTSP) serta Dinas Koperasi UKM Perindustrian dan Perdagangan (DKUPP). Dalam implementasi kebijakan penataan minimarket, DPMPTSP berfungsi sebagai lembaga pemberi perizinan bagi pelaku usaha minimarket, sedangkan fungsi DKUPP adalah sebagai pembinanya.

Selain kedua SKPD tersebut, implementasi kebijakan penataan minimarket juga melibatkan Kecamatan dan Desa/Kelurahan. Proses perizinan untuk pendirian dan operasional minimarket tentu diawali dengan rekomendasi dari desa/kelurahan yang dilanjutkan dengan keluarnya rekomendasi dari kecamatan.

Pelibatan kecamatan, dan terutama desa/kelurahan, dalam implementasi kebijakan penataan minimarket sangat tepat mengingat kedua lembaga pemerintah tersebut tentu sangat memahami kondisi daerahnya. Akan tetapi, keterlibatan kecamatan dan desa/kelurahan sering kali disalahartikan oleh para pelaku usaha minimarket. Diketahui bahwa ada pelaku usaha yang menganggap bahwa pendirian dan operasional minimarket cukup hanya dengan rekomendasi dari desa/kelurahan dan kecamatan. Akibatnya, ada minimarket yang beroperasi tanpa melengkapi izin usaha sebagaimana ketentuan yang berlaku.

Bupati Bandung, Dadang M. Naser, menyebutkan bahwa di kawasan komersial banyak minimarket yang tak berizin. Camat diintervensi desa, sementara desa merasa telah ada izin tetangga (lingkungan sekitar), selanjutnya pengusaha minimarket merasa telah keluar izin operasionalnya. Padahal kecamatan tidak berkewenangan mengeluarkan izin pendirian minimarket. Izin pendirian minimarket harus dari 
DPMPTSP melalui rekomendasi DKUPP (https://news.detik.com, 22-9-2017).

\section{Tepat Target}

Sasaran atau target kebijakan yang tertuang dalam bentuk Perda No. 20 Tahun 2009 adalah terwujudnya kemitraan serta keselarasan usaha antara UMKM, koperasi, pasar tradisional dan pasar modern. Salah satu jenis pasar modern adalah minimarket. Dengan demikian, minimarket tidak tergolong sebagai UMKM meskipun dari besaran modal serta omzet memenuhi kriteria sebagai UMKM.

Bentuk dari keselarasan usaha antara pedagang eceran tradisional dan minimarket antara lain adalah tidak terjadinya persaingan yang tidak sehat. Oleh karena itu, pendirian minimarket harus mempertimbangkan kondisi lingkungan usaha sekitarnya, dalam arti minimarket sebisa mungkin tidak mematikan pedagang-pedagang tradisional yang telah ada. Kebijakan penataan minimarket oleh karenanya mengatur jarak antarminimarket serta lokasi-lokasi yang diperbolehkan untuk pendirian minimarket.

Berdasarkan hasil observasi, ternyata terdapat minimarket yang letaknya saling berdekatan, hanya dipisahkan oleh beberapa toko, atau bahkan berhadapan hanya dipisahkan oleh jalan. Sebagai contoh adalah yang terjadi di Jalan Cikalang Kecamatan Cileunyi. Pada ruas jalan yang hanya sepanjang kira-kira 1.000 meter tersebut, terdapat lima minimarket, masing-masing tiga Indomaret dan dua Alfamart.

Contoh kasus lainnya adalah yang terjadi di Jalan Cikandang Kecamatan Cileunyi yang tergolong sebagai jalan desa, terdapat dua minimarket yakni Indomaret dan Alfamart yang letaknya berhadapan. Meskipun berdekatan dan tetap kondusif, namun terjadi persaingan di antara keduanya dan berpotensi menimbulkan gejolak yang dapat mematikan satu sama lainnya. Apalagi di lokasi tersebut terdapat banyak warung kelontong yang sifatnya usaha mikro dan tradisional. Kondisi yang sama juga terjadi di Kecamatan Rancaekek. Bahkan di kecamatan ini terdapat beberapa minimarket yang jaraknya berdekatan dengan pasar tradisional (berjarak kurang dari 200 meter).

Bupati Bandung, Dadang M. Naser, tidak menyangkal jika di daerah yang dipimpinnya masih banyak minimarket yang berdiri di jalan desa dan berdekatan dengan pasar tradisional (https://news.detik.com, 229-2017). Fenomena-fenomena tersebut menunjukkan bahwa beberapa minimarket telah menyalahi aturan sebagaimana tercantum dalam Perbup No. 60 Tahun 2014 yang merupakan petunjuk pelaksanaan bagi kebijakan penataan minimarket.

Tabel 2. Minimarket di Kecamatan Cileunyi dan Rancaekek Berdasarkan Kelengkapan Izin Usaha

\begin{tabular}{|c|c|c|c|c|}
\hline \multirow{2}{*}{ No } & \multirow{2}{*}{$\begin{array}{c}\text { Keca- } \\
\text { matan }\end{array}$} & $\begin{array}{c}\text { Leng- } \\
\text { kap }\end{array}$ & $\begin{array}{c}\text { Tidak } \\
\text { Lengkap }\end{array}$ & $\begin{array}{c}\text { Jum- } \\
\text { lah }\end{array}$ \\
\hline 1 & Cileunyi & 31 & 33 & 64 \\
\hline 2 & Rancaekek & 42 & 9 & 51 \\
\hline
\end{tabular}

Sumber: BPS Kabupaten Bandung, 2018

Selain tata letak yang tidak sesuai, masih ada minimarket yang tidak melengkapi izin usaha. Diketahui bahwa di Kecamatan Cileunyi masih terdapat 33 gerai minimarket yang tidak lengkap perizinannya, sedangkan di Kecamatan Rancaekek ada 9 gerai dengan kondisi serupa. Dengan kata lain, sasaran kebijakan minimarket belum tercapai sepenuhnya.

\section{Tepat Lingkungan}

Implementasi kebijakan memerlukan koordinasi internal dan eksternal. Koordinasi internal merupakan interaksi di antara lembaga-lembaga yang terlibat sebagai pelaksana kebijakan, sedangkan koordinasi eksternal condong pada upaya sosialisasi serta penjaringan opini atau persepsi publik 
atas kebijakan yang diimplementasikan. Dalam kasus kebijakan penataan minimarket, koordinasi antarlembaga pelaksana tercermin salah satunya pada penerbitan izin usaha minimarket.

Sebagaimana telah diatur dalam Perda No. 20 Tahun 2009 dan Perbup No. 29 Tahun 2010, izin minimarket diterbitkan oleh Bupati Bandung c.q. Dinas Penanaman Modal dan Pelayanan Terpadu Satu Pintu (DPMPTSP) atas rekomendasi dari Dinas Koperasi, Usaha Mikro, Perdagangan dan Perindustrian (DKUPP). Sebelumnya pelaku usaha minimarket harus memperoleh rekomendasi dari camat dengan melampirkan pengantar dari kepala desa/lurah. Melihat urutan pemerolehan izin tersebut, terdapat proses berkesinambungan mulaidaridesa/kelurahan hingga DPMPTSP. Pada kenyataannya, masih ada minimarket di Kecamatan Cileunyi dan Rancaekek yang hanya 'mengantongi' rekomendasi dari camat sehingga secara formal dianggap tidak memiliki izin usaha. Kondisi tersebut sekaligus menunjukkan kurangnya koordinasi di antara lembaga pemberi izin serta kurangnya sosialisasi kebijakan penataan minimarket kepada para pelaku usaha.

Kurangnya sosialisasi tentang Perda dan Perbup yang mengatur antara lain tentang penataan minimarket di sisi lain juga menunjukkan lemahnya interaksi dengan lingkungan eksternal kebijakan. Dalam implementasi sebuah kebijakan, termasuk kebijakan penataan minimarket, langkah sosialisasi merupakan hal yang penting. Melalui sosialisasi, diharapkan masyarakat, terutama pelaku usaha atau pemilik minimarket, mengetahui serta memahami kewajiban dan larangan yang harus dipatuhi guna menjalankan usahanya. Akibat kekurangpahaman perihal aturan yang berlaku, maka banyak minimarket didirikan dan menjalankan operasi usahanya dengan tanpa dilengkapi Izin Usaha Toko Modern (IUTM) sebagaimana yang disyaratkan.
Koordinasi yang kurang baik juga terjadi dalam hal pendataan dan penertiban terhadap minimarket yang menyalahi aturan. DKUPP yang berwenang melaksanakan pembinaan dan pengawasan terhadap minimarket seolah-olah bekerja sendiri.idealnya, tindakan pengawasan dan penertiban dilaksanakan dengan melibatkan lembaga lain, misalnya pihak kecamatan dan Satuan Polisi Pamong Praja (Satpol PP). Ada kesan bahwa setiap hal menyangkut keberadaan minimarket seluruhnya menjadi tanggung jawab DKUPP. Demikian pula halnya dalam pengambilan tindak penertiban terhadap minimarket yang tidak memiliki IUTM, di mana DKUPP hanya didukung oleh Satpol PP. Sebagai contoh adalah tindak penyegelan minimarket pada akhir tahun 2017 yang dilaksanakan oleh DKUPP bersama-sama dengan Satpol PP Kabupaten Bandung. Pada saat itu, sebanyak 115 minimarket di Kabupaten Bandung, satu di antaranya di Kecamatan Cileunyi, terpaksa disegel karena diduga melanggar Perda.

Guna mengatasi berbagai masalah menyangkut keberadaan pasar tradisional dan pasar modern, termasuk penataan minimarket, Pemerintah Kabupaten Bandung telah melakukan berbagai upaya. di antara upaya yang dilakukan adalah dengan menetapkan peraturan baru berupa Perda No. 2 Tahun 2016 tentang Penyelenggaraan Pasar. Akan tetapi sampai dengan saat ini belum ditetapkan Perbup sebagai petunjuk pelaksanaannya sehingga Perda tersebut belum dapat diimplementasikan secara optimal.

Upaya lain yang dilakukan adalah dengan mempermudah proses dan prosedur perizinan di DPMPTSP. Untuk keperluan tersebut, DPMPTSP telah menyelenggarakan pelayanan perizinan secara online melalui aplikasi Sistem Layanan Online Cetak Sendiri (Siloncer) dan Integrasi Sabilulungan Sistem Informasi Perizinan Terpadu Online Single Submission (Samirindu OSS). 
Kepala DPMPTSP Kabupaten Bandung, Ruli Hadiana, menyatakan bahwa aplikasi Siloncer memungkinkan pemohon izin mendapatkan izin usaha dengan mengakses website DPMPTSP. Pemohon dapat mengakses Samirindu di website DPMPTSP. Selanjutnya pihak DPMPTSP menyetujui atau menolak pemenuhan komitmen. Apabila disetujui, maka DPMPTSP akan melakukan survei kepuasan masyarakat dan pemohon izin dapat mencetak izin usaha melalui Siloncer (www.soreangonline.com, 8-122018). Melalui sistem tersebut, para pelaku usaha di Kabupaten Bandung diharapkan dapat memproses perizinan sesuai dengan peraturan dan ketentuan.

\section{SIMPULAN}

Kebijakan penataan minimarket di Kecamatan Cileunyi dan Rancaekek Kabupaten Bandung diketahui belum terimplementasikan secara efektif. Meskipun sudah tepat kebijakan dan tepat pelaksana, namun diketahui bahwa kebijakan tersebut belum tepat target dan tepat lingkungan. Beberapa hal mengemukayang menunjukkan bahwa kebijakan penataan minimarket di kedua kecamatan tersebut belum efektif antara lain adalah:

1. Masih ada minimarket yang menjalankan operasi usahanya dengan tanpa dilengkapi Izin Usaha Toko Modern (IUTM).

2. Tidak dipatuhinya ketentuan jarak minimal antargerai oleh beberapa minimarket. Bahkan ada minimarket yang lokasinya saling berhadapan atau berada dalam jarak yang sangat dekat (kurang dari 200 meter).

3. Masih ada minimarket dengan jam buka yang menyalahi ketentuan, bahkan buka 24 jam.

4. Koordinasi yang lemah antarlembaga pelaksana kebijakan serta kurangnya sosialisasi Perda dan Perbup. Hal ini berakibat pada rendahnya kepatuhan pelaku usaha minimarket terhadap peraturan yang berlaku.

5. Harapan terjadinya kemitraan antara minimarket dengan pelaku usaha mikro dan kecil belum terwujud.

6. Masih ada kesan terjadinya persaingan usaha yang kurang sehat, baik di antara sesama minimarket maupun antara minimarket dengan para pedagang kecil (pedagang tradisional).

\section{DAFTAR PUSTAKA}

Darsono dan Siswandoko, Tjatjuk. 2011. Sumber Daya Manusia Abad 21. Jakarta: Nusantara Consulting.

Idrus, Muhammad. 2016. Metode Penelitian Ilmu Sosial Pendekatan Kualitatif dan Kuantitatif. Jakarta: Erlangga.

Iskandar, Jusman. 2005. Manajemen Publik. Bandung: Penerbit Puspaga.

Mahmudi. 2013. Manajemen Kinerja Sektor Publik. Yogyakarta: UPP STIM YKPN.

Mardalis. 2014. Metode Penelitian Suatu Pendekatan Proposal. Jakarta: Bumi Aksara.

Nugroho, Riant, 2008. Public Policy. Jakarta: Elexmedia Komputindo.

Sedarmayanti. 2009. Sumber Daya Manusia dan Produktivitas Kerja. Bandung: CV Mandar Maju.

Silalahi, Ulber. 2011. Studi Ilmu Administrasi: Konsep, Teori, dan Dimensi. Bandung: Sinar Baru.

Soleh, Chabib dan Suripto. 2011. Menilai Kinerja Pemerintahan Daerah. Bandung: Fokusmedia.

Sugiyono. 2014. Memahami Penelitian Kualitatif. Bandung: Alfabeta.

2017. Metode Penelitian Kuantitatif, Kualitatif dan $R \& D$. Bandung: Alfabeta.

Suharto, Edi. 2010. 2011. Kebijakan Sosial sebagai Kebijakan Publik. Bandung: Alfabeta.

Uha, Ismail Nawawi. 2014. Manajemen Perubahan: Teori dan Aplikasi pada Organisasi Publik dan Bisnis. Bogor: Ghalia Indonesia. 
Wahab, Solichin Abdul. 2011. Pengantar Analisis Kebijakan Publik. Malang: UMM Press.

\section{Peraturan Perundang-Undangan}

Peraturan Menteri Perdagangan Republik Indonesia No. 68/M-DAG/PER/10/2012 tentang Waralaba untuk Jenis Usaha Toko Modern.

Peraturan Daerah Kabupaten Bandung No. 20 Tahun 2009 tentang Pembangunan, Penataan dan Pengendalian Pasar.

Peraturan Bupati Bandung No. 60 Tahun 2014 tentang Perubahan atas Perbup No. 29 Tahun 2010 tentang Petunjuk Pelaksanaan Perda No. 20 Tahun 2009 tentang Pembangunan, Penataan dan Pengendalian Pasar.

\section{Sumber Lain}

https: / / news.detik.com / berita-jawabarat/d-3654068/40, 40 Mini Market Disegel, Bupati Bandung: Tidak Boleh di Jalan desa, 22 September 2017.

h t t p s : / / w w w. a y o b a n d u n g. c o m / $\mathrm{read} / 2018 / 03 / 19 / 30316, \quad$ UMKM Kabupaten Bandung Kesulitan Tembus Minimarket, Senin, 19 Maret 2018.

https://www.soreangonline.com/2018/12, Pemkab Bandung akan Permudah Proses Perizinan, 8 Desember 2018. 